\title{
ALIENATED LABOR'S HYBRID SUBJECTS: SORRY TO BOTHER YOU AND THE TRADITION OF THE ECONOMIC RIGHTS FILM
}

\author{
Leshu Torchin
}

Reviews of Boots Riley's Sorry to Bother You (2018) appeared to struggle with how to assign it a classification. The story of Cassius "Cash” Green (LaKeith Stanfield), telemarketer on the rise in an alternative or speculative future version of Oakland, California, is "difficult to describe . . . Afrofuturist . . A Afrosurrealist," "a sci-fi socialist satire masquerading behind a sketch comedy premise," or maybe just "the most shocking anti-capitalist film ever."

But why choose? All these descriptions apply in the story of Cash, the film's protagonist, who by virtue of his name is caught up in the monetary system from the start. Living in a garage and trapped in debt, he takes a job as telemarketer with the RegalView corporation, where, by adopting a "White Voice," he is able to rise through the ranks to become a "Power Caller." While his friends and coworkers are protesting on the ground floor, he moves upward into a world of material wealth and away from entrapment in "the WorryFree solution": a life-long contract that offers unlimited labor in exchange for food and shelter. But with this new position comes even more insight into the scope of corporate abuse, due to the nature of his sales calls_-weapons and slave labor-and entry into a disturbing plot to produce a dehumanized workforce. All these attempts at description barely account for the wild brilliance of the film and the tools it employs to map out the transhistorical intersections of race, slavery, and capitalism —old-school and late-stage.

Sorry to Bother You's playful combinations of science fiction, performance art, and even corporate-video mockumentary invoke recent experimentations in black American media. Its strategies challenge limits of genre, platform, and racial identities in ways akin to the television program Random Acts of Flyness (Terence Nance, HBO, 2018-) and the "emotion picture" Dirty Computer (Janelle Monae, 20I8).

Film Quarterly, Vol. 72, Number 4, pp. 29-37, ISSN 0015-1386, electronic ISSN 1533-8630. (c) 2019 by The Regents of the University of California. All rights reserved. Please direct all requests for permission to photocopy or reproduce article content through the University of California Press's Reprints and Permissions web page, http://www. ucpress.edu/journals.php?p=reprints. DOI: https://doi.org/10.1525/FQ.2019.72.4.29

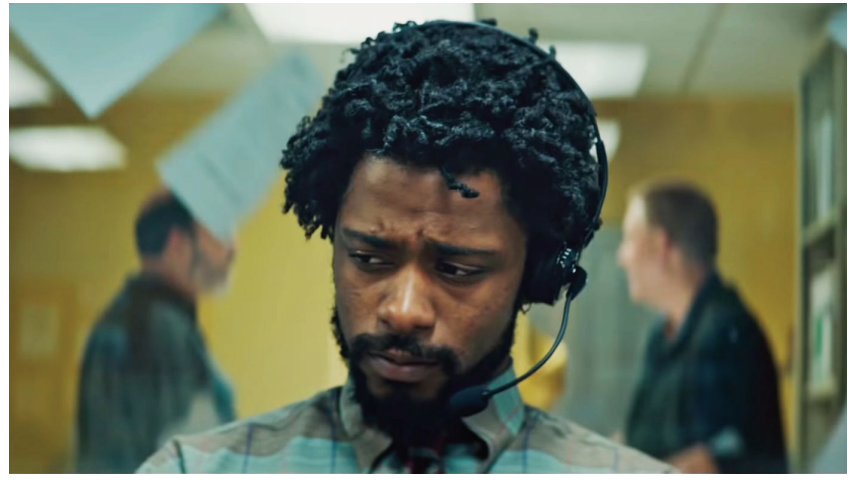

Cassius "Cash" Green (LaKeith Stanfield) at work in the call center.

In legacy terms, it can be seen as extending early experiments with race, genre, and black identity as seen in Watermelon Man (Melvin Van Peebles, I970), Chameleon Street (Wendell B. Harris Jr., I990), and Symbiopsychotaxiplasm: Take One (William Greaves, I968), a landmark metadocumentary reflection on performance, reality, and perspective. Sorry's hybrid formations combine with preoccupations around labor to position the film equally within a robust legacy of a more sober form: what can be called "economic rights" films. Often global in scope, these films argue for rights to sustenance, shelter, education, health, and labor while mapping out the myriad systems that impede access to these rights and produce harm. Sorry's mixture of traditions reorients the macro perspective of the global vision, crucially centering race in its inquiry.

\section{Economic Rights Films}

The category of the economic rights film is a broad one, spanning the globe, multiple periods, and diverse movementsfrom the Latin American political cinemas of decolonization to WTO protest documentaries, culture jamming, and documentaries responding to the global financial crisis. They both map out financial systems and present the injury those systems pose to the human and nonhuman (as the Anthropocene 
comes to the fore). More importantly, they present this injury as violation. Poverty, debt, and precarity can be seen not as results of misfortune or moral failing, to be remedied by philanthropy or self-help, but rather as threats to human dignity and safety that require political, social, and economic change, whether through the legislative frameworks that a rights imaginary allows or through forms of collective action and solidarity fostered in shared outrage and recognition of sanctioned abuse. Their wide range of tactics is shifting the discourse.

Although politics are changing with the rise of the Indignados, Occupy, and Gilets Jaunes movements, problems of perception linger. If the vivid depictions of political rights struggle to achieve justice, what hope is there for depictions of economic rights? Not only are these rights less acknowledged, particularly in the United States in the wake of accelerated deregulation and privatization, but they are challenging to represent. Financial systems operate at a level of abstraction and are treated as objective, autonomous, indifferent, or even inevitable. These are just numbers, after all, functioning in all rationality. The human effects of these systems-particularly global capitalism as the dominant system in operationare seen as incidental, or as part of a crisis; they are rarely seen as a result of a humanly created system working according to design.

Such popular understandings are not aided by "media amnesia," the term that Laura Basu has coined for the continual reframing of economic crisis in news media that both forgets and maintains the conditions that have led to the situations reported. This crisis narrative renders the system and its problems as "fluid, malleable, and difficult to grasp" and ultimately beyond anyone's control. And by "forgetting its own very recent coverage [it] has helped trap us in a neoliberal groundhog day." There is little assistance available from a sector beset by staffing cuts and "churnalism," both of which impede long-form, in-depth reportage. ${ }^{3}$

Films - particularly documentaries - have been countering this amnesia. The Corporation (Mark Achbar and Jennifer Abbott, 2003) seizes on the personhood of corporations granted by an I 886 case in the United States and regranted in cases across the centuries. Centering on this perceived humanity, the film notes that if the corporation were a person, it would be diagnosed as psychopathic in its reckless disregard for the safety and well-being of others. Setting aside briefly concerns over its use of mental health as stigma, what is valuable is the film's presentation of a human interaction to redress the abstraction and neutrality attributed to financial institutions, ostensibly governed by numbers.
Other films that bridge this gap between corporate practice and human effects include films by or about cultures jammers like The Yes Men (Chris Smith, Sarah Price, Dan Ollman, 2004) and Český sen (Czech Dream, Vit Klusák and Filip Remunda, 2004) or films that map out global trade and labor to suggest that poverty reveals a system working exactly as intended, as in Darwin's Nightmare (Hubert Sauper, 2006) and Black Gold (Nick Francis, 2006). And some films in the wake of the global financial crisis have sought to demonstrate this crisis as endemic rather than exceptional, such as Inside Job (Charles Ferguson, 2010) and Cleveland vs. Wall Street (Jean-Stéphane Bron, 20Io).

Although documentary supplies the journalistic and authoritative heft required to counter media amnesia, fiction does this work, too. Abderrahmane Sissako's Bamako (2006) features a courtyard tribunal where Africans charge the International Monetary Fund (IMF) and the World Bank with crimes against humanity and uses the Western, as film within a film, to depict the neocolonial violence of global capitalism. The Other Guys (Adam McKay, 2010) uses the spectacular pyrotechnics reserved for action films to tell the story of (ultimately unpunished) financial malfeasance. Still, the genre play of both films includes documentary elements. Bamako uses real-life jurists alongside its actors and seems to refer to the 2006 World Social Forum (held in Bamako), whose participants sought to mobilize a political, economic, and cultural consensus - and solidarity - against neoliberal globalization. The Other Guys concludes with a credit sequence that highlights statistics of corporate bailouts and the 2008 financial crisis. It is a reminder that these films, like the inventive Sorry to Bother You, are grounded in an alarming reality.

Race is not forgotten in the economic rights film, but it can be lost to a world-systems perspective that views race through nations, or through first and third worlds, while more nationally grounded approaches elide race in favor of class. With gestures to slave labor and with a White Voice literally provided by white actors, race is never incidental to Sorry's anticapitalist story. Its setting in Oakland tacitly articulates the enmeshment of race and economic inequality and exploitation. Birthplace of the Black Panthers and home to a majority population of people of color, the city is a site of ongoing displacement, uneven development, and disproportionate access to affordable housing and employment facilitated by gentrification and venture capitalism. ${ }^{4}$ Sorry has reminders of the intersections of political and economic systems throughout - expressed, for instance, in the exhibition of sculptures of Africa by artist and activist Detroit (Tess Thompson). This is where humanity started, she explains, but also where capitalism started, through the exportation of 


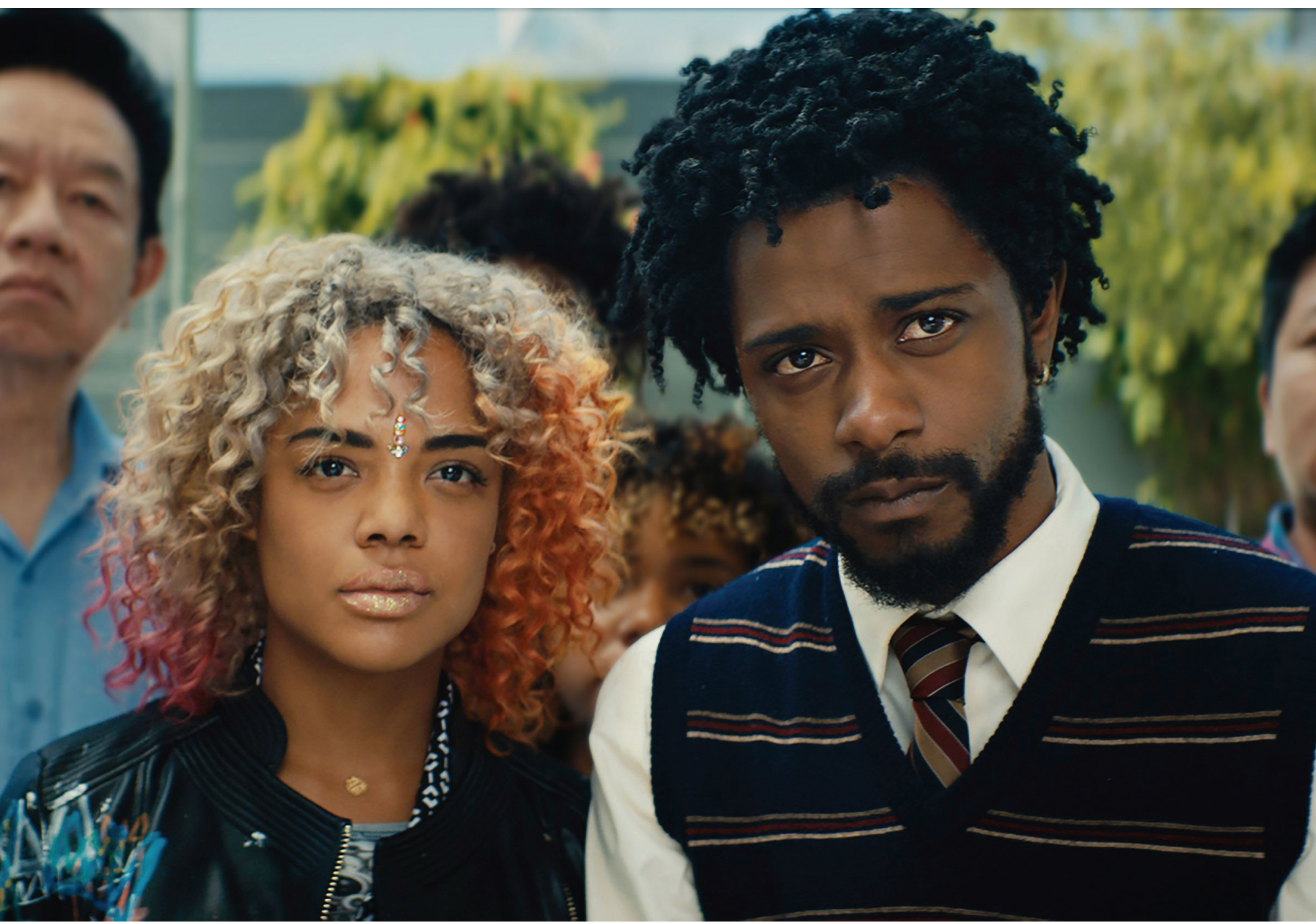

Cash (LaKeith Stanfield, right) with his artist/activist girlfriend Detroit (Tess Thompson, left).

Africans for labor. The old crimes have not been ended; they have only mutated and adapted.

Riley brings the uneven development frequently ascribed to postcolonial nations to the "here" of the Global North. In a world dominated by screens and phones, where televisions and telemarketers virtually connect people and information, Cash's girlfriend, Detroit, sells material objects—manufactured signs — on the street. Spinning the panels for passing cars, she is often shown alone, isolated even out in the physical world. It is a fitting image for a city in such close proximity to San Francisco and Cupertino- spaces so radically transformed by digital tech industries that they are increasingly accessible only to the wealthiest. In this city, she wields a physical sign in a world of pop-up Internet advertisements; and her art of billboard corrections and visceral performance pieces asserts a bodily materiality that risks going unseen.
Cash's workplace, RegalView, is unevenly dispersed. At the ground level, the space is crowded with cubicles, papers, electrical wires, and people, but the Power Caller suite upstairs is spacious and quiet, luxurious in its offering of calm elegance above the frenzied struggle for survival below. Its minimalist opulence is close to yet distant from both the daily labor abuses of a workforce readying for a strike and the products that it sells: arms and slaves. The capitalist logic conceptually disarticulates the WorryFree company's debt bondage program from its historical roots. (Its contract is a matter of "choice" to its defenders). Yet its pitch rests alongside the technologics that allow arms merchants and drone operators to distance themselves from the material violence wrought by their weaponry. Cash's guide, a well-dressed man known otherwise as $\mathrm{Mr}$. (Omari Hardwick), explains the process: "Before a drone drops a bomb on an 
apartment building in Pakistan, who drops the bomb-ass sales pitch?" This Power Caller pitch reveals the multiple connections and dislocations enabled by capital, technology, and violence.

\section{Slavery and the Carceral Imaginary}

Boots Riley initiates a rhetoric of political and civil rights violations through his invention of the WorryFree company, which offers "customers" a lifetime labor contract that comes with a guarantee of shelter and food - all contained within the same center. Television commercials and billboards saturate the film's landscape, advertising "state of the art" living quarters, delicious meals, and a fulfilling life. Yet the ostensibly chic decor of these accommodations fails to mask its prisonlike cramped efficiency: six bunk beds to a room, where people eat from the meal trays of correctional facilities. Identifying the arrangements as modern slavery, the film's "artivist" protester Left Eye begins to deface WorryFree billboards in a style reminiscent of the culture-jamming Billboard Liberation Front, altering them with spray paint and stencils that spell "slaves."

While these references to slavery and bondage- both financial and physical-refigure capitalism as an explicit violator of human rights, the carceral imagery equally recalls the very real ways in which slavery has been perpetuated in the United States through the prison system. It gestures to the disproportionate incarceration of black Americans and the widespread convict-leasing programs that provide cheap labor for the state. ${ }^{5}$

Riley's version of the prison-industrial complex expands into a world beyond the physically carceral. Entertainment culture is seen as complicit through such television programming as MTV Cribs: WorryFree Edition, where "contracted" inmates offer tours of the complex. The program sells

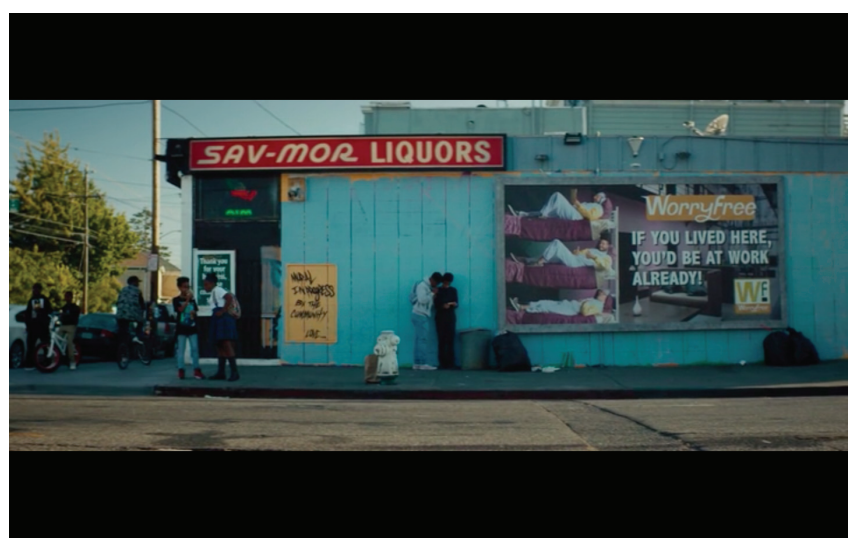

A billboard for WorryFree's accommodations. bondage as both aspiration and diversion. Human abjection offers spectacular recreation, as emphasized in the next program that Cash watches, I Got the S\#*@ Kicked Out of $\mathrm{Me}$, where contestants endure beatings and humiliations for financial reward. Media and ideology here fuse with finance and labor, placing the body in bondage and in harm's way.

As absurdist as this speculative fiction might seem, the conditions of wage slavery pictured in WorryFree's program are not only possible but actual, as evidenced in such documentaries as Stephanie Black's H-2 Worker (1990) and Life and Debt (200I). In these explorations of national and international financial policies and practices, Black highlights their links to slavery, deploying an iconography of captivity that illustrates the damage of global capitalism and its institutions.

$H_{-2}$ Worker, which takes its title from the $\mathrm{H}-2$ visa "guest worker" program, focuses on the seasonal laborers from Jamaica and the Caribbean who come to Florida to harvest and process sugarcane. Black draws a connection between the 1943 indictment of the U.S. Sugar Corporation for conspiracy to enslave black American workers and the current $\mathrm{H}-2$ program, which, she argues, perpetuates this same slavery. Black shows the decrepit conditions of the barracks, where shadows and framing highlight the confinement of supposedly free people. In interviews, workers describe food that does not meet the necessary standards of nutrition and the culture of fear that impedes organized protest; one pronounces this place to be like a prison. The suggestion that the new (then) plantation and its importation of labor bears something in common with the old version is underlined by the film's arrival sequence: under cover of night, workers disembark from a crowded plane, walking in a slow procession over the tarmac in a ritual that evokes the silhouette of a slave coffle.

Black's Life and Debt shows debt bondage writ large through structural-adjustment programs, whereby decolonized nations work to pay back their development loans to global financial institutions: the IMF and the World Bank. One segment addresses the physical appearance of free-trade zones: winding mazes of iron bars, barbed wire, and signs demanding worker and visitor compliance, evoking not so much the carceral as the "concentrationary" universe. This is a site where people are made into captives, treated as disposable labor, as less than human. Moreover, the dehumanization is not confined to the camps, but is part of a larger political logic that has made them possible. For David Rousset and the theorists who have followed him, the "concentrationary" universe connects not only to totalitarianism and imperialism, but to capitalism as well. ${ }^{6}$ 
Sorry to Bother You communicates the continuing legality of such setups when WorryFree is exonerated of all charges of slavery. Both the fictional state and the company's CEO, Steve Lift (Armie Hammer), declare participation in the program to be voluntary and beneficial to the economy. This defense is hardly speculative: in the offscreen world, disparity, asymmetry, and harm are already embedded in the ostensibly legal economic policies chronicled in economic rights documentaries.

\section{Mobility's Confinements}

The use of carceral imagery in movement and labor signals the many curious confinements in an age of accelerated mobilities. Although the idea of cross-national flows of people strikes terror in the hearts of Brexiteers and MAGA-hat wearers (among others), this fear distracts from the flows of finance and technology more likely to benefit from the increasingly porous borders of globalization. Although one might have expected the $\mathrm{H}-2$ visa scheme to be canceled under the Trump administration, such was not the case. In July 2017 , the guest worker visa cap was lifted, and some of the first beneficiaries of this increase were Trump's businesses.

Arjun Appadurai accounts for such intersections and disjunctures with the concept of "scapes." These refer to the flows of people ("ethnoscapes"), capital ("financescapes"), technology ("technoscapes"), media ("mediascapes"), and ideology ("ideoscapes"). His multiscape framework accounts for the shifting perspectives, changing relationships, and surprising contradictions of globalization-its fluidity, amorphousness, and contingencies. He offers an appealing metaphor that allows for reflection on the new places and populations that emerge in sites of convergence. ${ }^{8}$

I suggest the addition of "laborscapes" to this confluence of flows. Suggestively spatial and dynamic, the term identifies and situates the curious phenomenon through which workers both travel and remain rooted. Enabled by finance and technoscapes and bolstered by ideologies that displace anxieties over global capitalism and erosion of national and cultural sovereignty onto movements of people, the laborscape defines labor as that which is extracted and exported onto a transnational field while its bodies are restrictedbound to specific localities and constant service.

Sorry to Bother You offers a fictional version of this laborscape in its attention to the interface of technology, labor, capital, and culture. As protected as the travel between privileged and unprivileged space may be - such as the comically long code required for the elevator up to the Power Caller suite- these flows erode boundaries between human space and work space. The film depicts Cash's phone calls as literal home invasions, as he and his desk plummet directly into the houses of those called. Capital and technology are able to penetrate any residual borders of privacy and boundaries of personal space. Cash's "Sorry to bother you" phrase that opens the script offers a curious mix: the residual space of human encounter in the form of an apology for this sort of intrusion and a corporate performance of faux sincerity to secure entry. This seeming freedom of movement is not entirely free, however, since Cash is trapped behind his desk in each of these scenarios. He cannot leave his post.

Alex Rivera has been a prominent interpreter and critic of these structures across a series of films. His early Why Cybraceros (I997) imagines a similar form of mobile confinement by combining science fiction and mockumentary into a five-minute spoof of the very-real promotional film Why Braceros (1959), issued by the Council of California Growers. Both films outline the temporary migrant programs that deliver Mexican labor to the U.S. agricultural sector. The original assures viewers that these guest workers pose no threat, but only economic benefit; they are not here to stay. Rivera's short offers a similarly delighted paean, only this time it's not the technology of a temporary visa but the technology of applied science and mechanics that contains the workers and their perceived threat. Using joysticks, this labor force controls orange-picking robots across the border and thus telecommutes, remaining "safely" ensconced within Mexico. "All the labor without the worker," as a voice-over enthusiastically reassures the viewer. The blond family that buys and drinks the final product of orange juice makes unquestionably evident the ideology of racial purity underpinning this endeavor.

The generic enmeshments of science fiction and mockumentary supply a mixed-mode articulation of the intersecting flows of capital, technology, and labor. Both genres provide their own mixture of actuality (science, documentary) and speculation (fiction, satire), communicating the destabilization of space and perception brought on by capital. The aspirations and fantasies of capitalism, the upward mobility and the desired rewards, mask the real lack — of mobility, of access, and of resources - felt by its inhabitants.

Rivera develops these themes much more fully in his feature-length science-fiction film, Sleep Dealer (2008), which further dramatizes this earlier speculative workplace; this time, flows of capital and technology penetrate national borders as well as human ones. Instead of joysticks, there are now wires inserted into the worker to produce a prescient hybrid subject: the human-machine interface. Workers are able to leave such places, but only to confront the multiple 


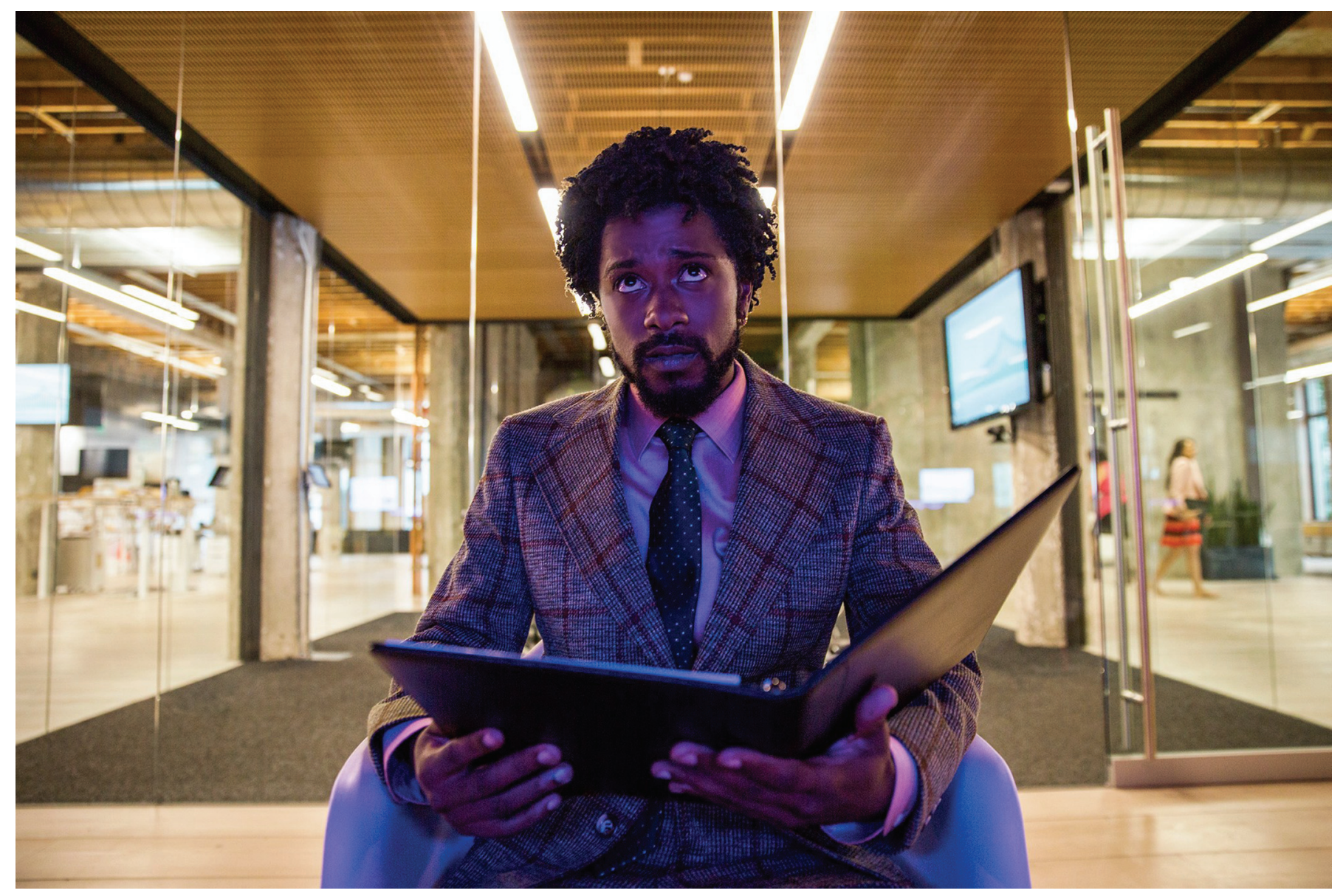

Cash (LaKeith Stanfield) in the "Power Caller" suite.

walls and dams of their living spaces. Here, too, political and civil rights tropes are deployed as violations enacted upon the body, all blocked and controlled by capitalism's logic.

\section{Border Zones and Hybrid Formations}

Even liminal spaces are not free from capital's logic. Border zones offer up sites of confluence and management. While the guest worker program exports laborers to operate in confined spaces, the maquiladora program keeps workers within national borders. Maquilapolis: City of Factories (Vicky Funari and Sergio de la Torre, 2006) looks at the foreignowned factories situated in the border town of Tijuana. The program's trade agreements have devastating repercussions on local workers, largely women, who are paid substandard wages, exposed to toxic chemicals, and live in regions unserved by any basic infrastructure-all with little recourse to action. Through stylized reenactments, these women communicate to the filmmakers and viewers the unseen work behind factory walls. Such sequences introduce a hybrid dimension to the fabric of the documentary, destabilizing borders between drama and documentary to re-create the spaces and experiences destabilized by the operations of capital and technology, which penetrate borders and, through toxic exposure and exploitative labor, poison people as well. ${ }^{9}$

Capital refigures space and experience throughout Sorry to Bother You. It begins in small ways, with erosions between work and leisure that are simultaneously sober and playful; classical editing, though, achieves other jarring effects. A simple shot/reverse-shot, for instance, produces a seamless transition of Cash from work to a bar with his friends. But while one semblance of spatial continuity is maintained, it is shattered by the assault on temporal continuity. Thus does the approved formal economy of film editing enable the timespace compression associated with global capitalism and the post-Fordist economy. And it only accelerates from there. WorryFree is a "revolutionary new business and lifestyle model," boasts a TV commercial, while a billboard reads, "WorryFree. If you lived here, you'd be at work already!"

The shaping of experience is a deeply human one. In one of Sorry to Bother You's most notable touches, Cash uses a White Voice to propel his workplace rise. Older telemarketer 
Langston (Danny Glover) explains that he cannot speak white enough to gain confidence and entry. ${ }^{\text {Io }}$ Cash must adapt and change himself to suit the market. Voiced by white actors, the on-screen speech realizes the double consciousness described by W. E. B. Du Bois, sociologist, activist, and author of science fiction. The manifestation of this speech speaks to the "twoness" and the "unreconciled strivings" of black Americans living under racism. ${ }^{\text {II }}$ To have another actor's voice emanate from LaKeith Stanfield's body makes material the estrangements that come with managing multiple perspectives and expectations.

Even with white actors supplying these White Voices, Riley does not traffic in essentialisms: the White Voice is something that is performative even for white people. “There ain't no real White Voice," explains Langston, "it's what they wish they sounded like." This White Voice is the sound of solvency, of debts paid or never accrued. According to David Cross, the actor who performs Cash's White Voice, "If you could put a Brooks Brothers jacket and a pair of Dockers on a voice, that's what we've got." For Riley, this is a "performance of whiteness that has to do with people aligning with their own oppression or aligning with their own oppressors." ${ }^{\text {I2 }}$ At the same time, there is no losing sight of the racial coding of a White Voice, which is marked and marketed as both successful and the opposite of blackness.

Cash's White Voice begins to escape the confines of the workplace and emerge in conversations with his friends and even in bed with Detroit. Nor are such intrusions innocent. The soirée of WorryFree's CEO, Steve Lift, like all work parties, occupies the uncomfortable and indeterminate space wherein a delicate balance of vocational competence and social belonging is performed. A forced musical performance amplifies the discomfort of this mixed space. Lift, surrounded by his white party guests, faces Cash, who sits alone, framed by a fireplace that evokes a theatrical proscenium arch as much as the confinement that lingers even with upward mobility. Lift demands he regale the guests with stories of "Oakland gangster shit." Cash is apologetic, explaining he has no such stories. "Well, give us something," Lift instructs him. "Give us something different. Take off the White Voice." Lift demands a rap, pulling in the insistent chants of the other predominantly white party guests. Eventually, and

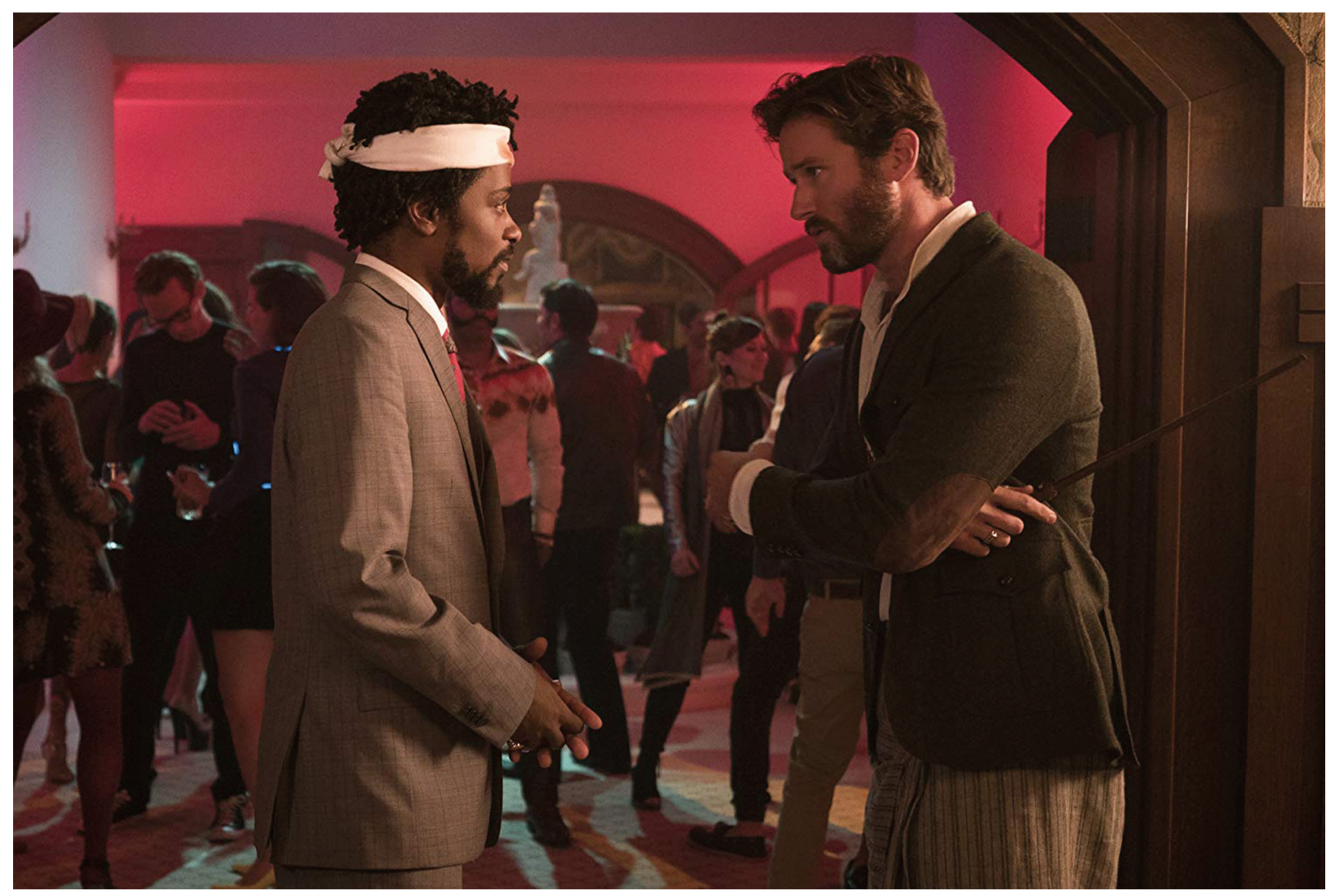

Cash (LaKeith Stanfield, left) and his boss (Armie Hammer, right) face off at the company party. 
painfully, this results in Cash's rap, "N-Word Shit," which acknowledges what is sought: the white perception of blackness as performed for whites by the black party guest who is always already performing, always already laboring, forced to do so by a pseudoagency that masks deeper servitude.

This alliance of racial performance with labor is an element shared by many economic rights films, again reflecting real-life practice. John \& Jane (Ashim Ahluwalia, 2006) explores multiple dislocations of Indian call-center workersvirtual migrants whose labor is exported through telephony and satellite technology. Demands of capital structure the lives of the workers in Ahluwalia's documentary, whether through graveyard shifts that accommodate the time zones of American clientele or cultural training that includes the adoption of an Anglo name, American accent, and U.S. trivia. The effects can be profound: its bleached-blond, blue-eyed Naomi fully inhabits her performed Americanness, embodying Marxist postindustrial alienation. Transformed into an appendage of the multinational machine, she is a mixture of the human she once was and the technologies of culture, finance, and labor that have taken root in her home, office, and in her body.

Sorry takes this kind of discomforting amalgamation into the realm of horror with the introduction of the "Equisapien," Lift's horse-human hybrid worker, a creature forged in the intersection of capital, technology, and labor. Invoking as it does the dehumanization of African American slave labor, the choice of horse is both canny and uncanny. The horse was a working animal, domesticated and drafted into service, which when it outlived its usefulness was transformed into a dead commodity: glue or leather. And a "workhorse" is a human who tirelessly tackles unpleasant and unskilled tasks. Meanwhile the sexual connotations of "hung like a horse" invoke the racialized fantasies of black genitalia and fear of the black penis that inhabit political and popular culture. A metaphor for labor as well as its literalization, grotesquely fantastic and fantastically grotesque, the Equisapien is reminiscent of the effects of capitalism's violations on actual humans, historical and fictional.

\section{Hybridity as Resistance}

As much as hybridity functions as an illustration of capitalism's uncanny effects on space, experience, and self, it equally has the capacity to provide a route to resistance. The brutal shock of Sorry to Bother You's Equisapien undermines hybridity's status as a beneficial evolutionary development, while the use of animation in a corporate video that introduces the invention offers a further modal instability. Given that Cash had encountered horrifically rendered live-action Equisapiens just earlier, the animation should not be dismissed as merely humorous or pragmatic. Too playful to be taken seriously, the animation confronts both the corporate logic that rationalizes this monstrous production and the documentary logic that lends such corporate videos their authority.

Such a tactic finds a precedent in Itha das Flores (Island of Flowers, Jorge Furtado, 1989), an earlier satire that mixes live action with animation to map out global capitalism and its effects on Brazilian life in the space of thirteen minutes. A transnational hit, it disrupts the seemingly transparent and neutral logics of finance on the one hand, and of documentary and the educational film on the other.

Amid the rightfully rave reviews of Sorry to Bother You, concern has been voiced about its supposed excesses. The AV Club suggests that the introduction of the Equisapien brings an "aggressive swerve" to the narrative. ${ }^{13}$ At the New York Times, Manohla Dargis praises the film but warns that it "slips into something of a mess." ${ }^{4}$ But none of this is a bad thing. The wildness of the narrative, whether praised or puzzled over, is essential to the resistance the film provides.

When introduced to RegalView, Cash is told, "Stick to the script," an instruction that adorns the walls for all employees to read and follow. With his mixture of forms and a narrative that upends expectation, Riley has produced a film that can resist the scripts of capitalism-including the expectations of the genre film, however confounding that may be to its fans.

The film offers three stages of an ending. First up is the happy resolution: Cash joins the Telemarketer's Union; all is well. But as he enters his apartment with Detroit, there comes a sign of his imminent transformation into Equisapien, a horrific reminder of capitalism's capacity to intrude into the home and the body. A smash cut to the film's credits suggests that this is the end, but no. There is a final sequence in which the Equisapien Cash, no longer alone, rings Lift through the intercom. "Sorry to bother you" he begins, before smashing the camera and entering Lift's home in a literal, bodily home invasion that upends his performative labor of the past. Bodily hybridity and narrative grafting merge at this moment into a scene of incipient revolution, the conclusion of which remains unknown.

This ending confronts capitalism and racism-and the racist order of capitalism — as well as the very real limits of the economic rights film. While they may present capitalism as perpetrator of poverty and violator of human dignity, such documentaries offer an organizing logic that, conceptually and politically, carries its own challenges. "Rights" have been the subject of critique for their ambiguity and for their 
association with neoliberalism, whether focused on an individual or yoked to development initiatives promoting economic liberalization. The reliance on existing frameworks for implementation may also impede imagining alternatives to collective action and participation. ${ }^{15}$ Further, there are severely reduced options for "human rights" when nations are already penetrated by transnational corporate forces. If the fight for rights relies on a figure that has been rendered abject, divested of rights and humanity, and visualized as such, then such representation becomes yet another form of performative labor disproportionately assumed by the black, foreign, or "other" body.

Sorry to Bother You succeeds by devising a satiric style and revolutionary conclusion that shakes up these critiques. Here the figure of abjection, whose human rights have been viscerally and visibly compromised for the sake of capitalism, is now an agent of collective action. Preceded by blaring alarms, Equisapien Cash enters the house and lets out a roar before the credit sequence returns. There is pointedly no resolution. Earlier, the film had offered one in the fate of the picket-line protester who hurled a soda can at Cash, became a meme, and was commodified as a television celebrity with a costume celebrating her act of violence. Sorry's final act, however, refuses containment and control. It's time to disturb everything, Riley seems to say at last: borders, capitalism, and how to think about rights.

\section{Notes}

I. Geoffrey Crété, "Sorry to Bother You: Start Up Critique," Ecranlarge.com, January 24, 2019, www.ecranlarge.com/ films/critique/I053245-sorry-to-bother-you-start-up-critique; William Hughes, "Good News, Sorry to Bother You Fans: Boots Riley is Writing a New Movie,” AV/News, January 24, 20I9, https://news.avclub.com/good-news-sorry-to-bother-youfans-boots-riley-is-wri-I832037982; Touré, "Sorry to Bother You: Is This the Most Shocking Anti-Capitalist Film Ever?" The Guardian, August I9, 2019, www.theguardian.com/film/ 2018/aug/Ig/sorry-to-bother-you-is-this-the-most-anti-capital ist-film-ever.

2. I use this term to describe films that illustrate and advance economic rights, as guaranteed in the International Covenant on Economic, Social, and Cultural Rights of the United Nations Human Rights Charter, which was ratified in I966 and entered into force on January 3, 1976. See www.ohchr. org/en/professionalinterest/pages/cescr.aspx.

3. Laura Basu, Media Amnesia: Rewriting the Economic Crisis (London: Pluto Press 2018).

4. City Rising, produced through a partnership between KCET and the California Endowment, is a series that takes up issues of gentrification and development in the state's cities through a cross-platform documentary; see www.kcet.org/ shows/city-rising. Barry Jenkins's Medicine for Melancholy (2008) addresses the threat of gentrification to the East Bay in its story of a San Francisco that increasingly has little space for a middle class.

5. This reality is the subject of Ava DuVernay's documentary I3th (2016).

6. David Rousset, L'Univers concentrationnaire (Paris: Hachette, I946/20 I I); Giorgio Agamben, Homo Sacer: Sovereign Power and Bare Life, trans. Daniel Heller-Roazen (Stanford, CA: Stanford University Press, I998); Griselda Pollock and Max Silverman, "Introduction: Concentrationary Cinema," in Concentrationary Cinema: Aesthetics as Political Resistance in Alain Resnais's Night and Fog, ed. Griselda Pollock and Max Silverman (Oxford and New York: Berghan Books, 20I I), I-54. Appealing as the recognition of the extended politics are, it is essential not to lose sight of the lived horror of the camps_-nor of slavery itself. Instrumentalizing violent experience in a generalizing metaphor risks minimizing that experience, and ironically reduces it to a commodity in an economy of metaphor.

7. Alexia Fernández Campbell, "Trump Lifted the Cap on H-2B Worker Visas. Then His Businesses Asked for 76 of Them," Vox, July 20, 20I7, www.vox.com/policy-and-politics/20I $7 / 7 /$ 20/I6003254/trump-h2b-visa-program.

8. Arjun Appadurai, "Disjuncture and Difference in the Global Cultural Economy," Theory, Culture \& Society 7, nos. 2-3 (June I990): 295-3I0.

9. The collaboration and cocreation between filmmakers and subjects in Maquilapolis produce a real value and added humanity for the figures who, as subjects, are too often treated as a commodity in the documentary storytelling economy.

Io. Danny Glover's casting enhances the film's anticapitalist themes. In addition to his work for the California Poor People's Campaign, Glover also appeared in Abderrahmane Sissako's Bamako (2006), mentioned above.

II. W. E. B. Du Bois, The Souls of Black Folk: Essays and Sketches (Chicago: A. G. McClurg, I903; New York: Johnson Reprint, I968). And thanks to Lisa Yaszek, "Afrofuturism, Science Fiction, and the History of the Future," Socialism and Democracy 20, no. 3 (November 2006): 4I-60; it was here that I first learned of Du Bois's short story "The Comet."

I2. Hunter Harris, "How Sorry to Bother You Found (and Used) Its White Voice," Vulture, July I8, 2018, www.vulture.com/ 201 8/o7/boots-riley-sorry-to-bother-you-found-and-used-itswhite-voice.html.

I3. Hughes, "Good News."

I4. Manohla Dargis, "At Sundance, Films Filled with Fury, Propelled by Outsiders," New York Times, January 25, 2018, www.nytimes.com/2018/or/25/movies/sundance-lizzie-sorryto-bother-you-skate-kitchen.html.

I5. A useful up-to-date review of critiques (and counterpoints) can be found in Malcolm Langford, "Critiques of Human Rights," Annual Review of Law and Social Science I4 (October 2018): 69-89. 